\title{
Towards a Conceptualization and an Operationalization of the Construct of Employee Engagement
}

\author{
Y. Anuradha Iddagoda ${ }^{1}$, H. H. D. N. P. Opatha ${ }^{1} \&$ Kennedy D. Gunawardana ${ }^{1}$ \\ ${ }^{1}$ Department of Human Resource Management, University of Sri Jayewardenepura, Sri Lanka \\ Correspondence: Y. Anuradha Iddagoda, Department of Human Resource Management, University of Sri \\ Jayewardenepura, Sri Lanka. E-mail: anuradha_iddagoda@yahoo.com
}

Received: October 22, 2015

Accepted: January 11, 2016

Online Published: January 25, 2016

doi:10.5539/ibr.v9n2p85

URL: http://dx.doi.org/10.5539/ibr.v9n2p85

\begin{abstract}
Employees are generally considered as the most important resource needed for an organization to achieve its main goals. Realization of goals achievement heavily depends on the extent to which these employees are engaged in their jobs and their organization. Employee engagement is a factor that contributes positively to employee productivity and then organizational effectiveness. It reveals that a conceptual confusion exists with regard to the meaning of employee engagement owing to that the concept has been defined by different scholars in different ways and also that there are several associated terms such as job satisfaction, job involvement, work involvement, organizational commitment and organizational citizenship behavior which have been used in the literature, either synonymously or non-synonymously. Further a question arises to decide whether employee engagement is an attitude or a behavior. This paper seeks to provide a comprehensive conceptualization of employee engagement that results in formulating a working definition for research purposes involving the construct, and to explore its dimensions and elements for the purpose of measuring the construct.
\end{abstract}

Keywords: conceptualization, employee engagement, operationalization

\section{Introduction}

Employee engagement is one of those often talked-about, but rarely understood concepts. Generally, an employer knows about the value of the happy and fulfilled employee, but the challenge is to attract and retain the happy and fulfilled employee for a business. Engaging employee is one of the solutions for this.

Employee engagement has become a buzz word in management circles, because it enables the organization to excel and gain competitive advantage. The employees who are engaged are often loyal, innovative, creative and customer oriented. They have an intention to stay with the company for a long term. Similarly, they are the people who do not hesitate to go an extra mile in order to achieve organizational goals. Joo and Mclean (2006) state that engaged employees are strong organizational assets for sustained competitive advantage, as well as a strategic asset. Macey and Schneider (2008), Macey et al. (2009), as cited in Shuck et al., (2011) point out that employee engagement is a dominant source of competitive advantage in many companies and organizations increasing workplace performance and productivity. Richman (2006) mentions, considering some studies, that it is obvious that high employee engagement leads to increased discretionary effort, higher productivity and lower employee turnover, high level of customer satisfaction and loyalty, profitability and shareholder value for the organization.

Lack of consensus on the meaning of employee engagement has been identified by Saks and Gruman (2014), parallel to a drastic absence of concerns about the validity of the most popular measure of employee engagement. Making causal conclusions about the antecedents and consequences of employee engagement has been constrained by various research limitations as well. Therefore, an attempt is made to deal with some unanswered questions and unfinished work in order to develop a theory of employee engagement.

This paper attempts to address:

1) Solving the existing confusion: the labels of engagement.

2) Solving the existing confusion: the meaning of employee engagement and the associated terms.

3) Is employee engagement a behavior or an attitude? 
4) Towards a working definition of employee engagement.

5) Operationalization of the construct.

\section{Sources of Data}

The archival method was used as a method to review the literature. The objectives of this paper are to provide a conceptual clarification for the existing confusion of the meaning of employee engagement and to develop an instrument of measuring the construct of employee engagement. The databases such as Sage, Taylor and Francis Online, Springerlink, ScienceDirect, JSTOR, Wiley Online Library and Emerald were used when searching for articles in order to get the data. And also relevant parts of many books were studied in detail.

\section{The Existing Confusion: Different Labels of Engagement}

There is confusion about the meaning of the construct of employee engagement evidenced by the use of different labels such as personal engagement, work engagement, job engagement and employee engagement. It is evident that many researchers have used these labels interchangeably. Saks (2006); Anaza and Rutherford (2012) talk-about job engagement in their studies. Bakker and Demerouti (2008); Gorgievski et al. (2010) and Karatepe (2011) use the term "work engagement". Guest (2014) mentions that the first paper on employee engagement was written by Kahn in 1990. Guest (2014) also mentions that he (Kahn, 1990) continued to write about the concept and defined employee engagement. But Kahn (1990) in his paper uses the term "personal engagement".

The authors that are included in Table 1 believe that there is a common thread between all the labels such as job engagement, organizational engagement, work engagement, personal engagement and employee engagement. Researchers of this paper also agree with them. Although typically "employee engagement", "job engagement", "organizational engagement" and "work engagement" are used interchangeably, researchers prefer the term "employee engagement". "Work engagement" sounds like the relationship of the employee with his or her work. The word "employee" is better to be used with "engagement" because the word employee represents a living being. Hence it should be "employee engagement" in job and organization.

Table 1. Authors believing a common thread in engagement labels

\begin{tabular}{|c|c|c|c|}
\hline & Author & Year & Source \\
\hline & Luthan, F. and Perterson, S.J. & 2002 & Emerald Database \\
\hline & Robertson, I.T. and Cooper, L.C. & 2009 & Emerald Database \\
\hline \multirow[t]{4}{*}{ Shuck, } & M.B., Rocco, T.S. and Albornoz, C.A. & 2011 & Emerald Database \\
\hline & Xu, J. and Thomas, H.C. & 2010 & Emerald Database \\
\hline & Anitha $\mathrm{J}$. & 2014 & Emerald Database \\
\hline & Guest, D. & 2014 & Emerald Database \\
\hline
\end{tabular}

\section{Solving the Existing Confusion: The Meaning of Employee Engagement and the Associated Terms}

The terminology is confused by interchangeable use of the labels of engagement, commitment and involvement in literature (Hallberg \& Schaufeli, 2006). Robinson et al. (2004) as cited in Saks (2006) mention that, to make matters worse, multiple definitions of employee engagement and the measures resonate with other well-established phenomena, such as organizational commitment and organizational citizenship behavior.

Hallberg and Schaufeli (2006) mention, however, that work engagement, job involvement and organizational commitment are clearly differentiated concepts; each with specific trademark. Saks (2006) points out that employee engagement is distinguishable from several related constructs, most notably organizational commitment, organizational citizenship behavior and job involvement.

\subsection{Employee Engagement and Job Involvement/Work Involvement}

Dunham (1984) mentions that the term involvement has been treated in many different ways by both researchers and practitioners. Some refer to "involvement" as actual behaviors in which people engage (such as attendance, timeliness and performance). Such a behavioral perspective is inappropriate. Involvement is an attitude and, as such, a variety of behaviors might be associated with a particular level of the involvement attitude. Because of these reasons, Dunham (1984) points out that involvement is treated as a psychological variable. According to Dunham (1984), there are two types of involvement; job involvement and work involvement.

Job involvement: Dunham (1984) states that this refers to an employee's involvement with or alienation from a specific job. Dunham (1984) further states that job involvement is an attitude which is influenced heavily by 
one's current job situation. Job involvement is also influenced by previous work experiences (but to a lesser extent than work involvement).

Work involvement: This refers to the involvement with or alienation from work in general. Dunham (1984) further states that involvement in work may be influenced by a variety of job experiences one has had during his or her life, but work involvement at a particular point in time is not influenced heavily by the job one has held at that specific point in time.

Dunham (1984) mentions that there are three components of work and job involvement that can be identified. They are listed below.

1) Conscious desire and choice to participate in work or a job: Dunham (1984) points out that this component is loaded with behavioral tendencies. The person who is high in this component wants to be physically and psychologically involved in work or the job. Dunham (1984) explains this by providing an example; if you sign up for a class and say "I'm really going to 'get into' this class," you are showing that you are high in this first component of involvement.

2) Degree to which an individual considers work or a job to be a central life interest: Dunham (1984) states that this is simply the degree to which work or the job is an important part of an employee's life. The view about this component by Dunham (1984) is that this does not imply any behavioral tendencies. Dunham (1984) further states that following statements might be made by a person who is high in the central life interest component of work/job involvement.

-The most important things that happen to me involve in my work/job

-The major satisfaction in my life comes from my work/job

- I live, eat and breathe in my work/job

3) The degree to which a person considers work or a job to be central to his/her self-concept: A person who is high in this component of involvement makes frequent reference to work or the job in evaluating himself/herself as a person. Dunham (1984) further states that if you ask "What kind of person am I?" and you answer by referring to work or job related factors, you are high in this final component of involvement.

According to Saks (2006), employee engagement differs from job involvement. May et al. (2004) state that job involvement results from a cognitive judgment concerning the needs that satisfy abilities of the job. Jobs in this view are tied to one's self-image. May et al. (2004) further state that employee engagement differs from job involvement for it is concerned more with how the individual employs his/her self during the performance of his/her job. Furthermore, employee engagement entails the active use of emotions and behaviors, in addition to cognitions. May et al. (2004) also state that, employee engagement may be thought of as an antecedent to job involvement in that individuals who experience deep engagement in their roles should come to identify with their jobs. Researchers do not agree with this view. The researchers' view is that there are similarities between job involvement and employee engagement. This is proved through the components of job involvement and work involvement by Dunham (1984). Job involvement is the degree to which a person chooses to participate in a specific job experience, considers the job to be a central life interest and considers the job central to his/her self-concept (Dunham, 1984 as cited in Opatha, 2012).

Job involvement measures the degree to which a person identifies psychologically with his or her job and considers his or her perceived performance level important to his or her self-worth. There is a high level of relationship between job involvement and fewer absences and lower resignation rates of an individual (Wegge et al., 2007; Allen et al., 2001). This caters to an attribute called "Stay" of AON Hewitt (2012). Engaged employees display an intense desire to be a member of the organization under "Stay".

Robbins and Judge (2013) define employee engagement as an individual's involvement with, satisfaction with, and enthusiasm for, the work she does. The view of Robbins and Judge (2013) is that involvement is a building block of employee engagement. Employee engagement refers to the individual's involvement and satisfaction with as well as enthusiasm for work (Harter et al., 2002). Researchers can say here that Harter et al. (2002) identified one component of employee engagement as "involvement". Maslach and Leiter (1998) as cited in Maslach et al. (2008) define employee engagement as an energetic state of involvement with personally, fulfilling activities that enhance one's sense of professional efficacy. They have also identified involvement as a component of employee engagement.

Employee engagement is different from job involvement, but there is a close relationship between the two. Byrne (2015) reveals studies given in the Table 2 which found moderate correlations. 
Table 2. Relationship between job involvement and engagement

\begin{tabular}{cc}
\hline Study (alphabetical order) & Correlation of job involvement with engagement \\
\hline Dalal, Baysinger, Brummel and LeBreton (2012) & .57 \\
Hallberg and Schaufeli (2006) & .35 \\
Kuhnel, Sonnentag and Westman (2009) & .30 and .32 \\
Rich, LePine and Crawford (2010) & .47 \\
Steele, Rupayana, Mills, Smith, Wefald and Downey (2012) & .54 \\
\hline
\end{tabular}

Source: Byrne (2015).

\subsection{Employee Engagement and Organizational Commitment}

Armstrong (2009) mentions that, as defined by Porter et al. (1974), commitment is the relative strength of the individual's identification with and involvement in a particular organization. Armstrong (2009) also mentions that there are three characteristics of commitment identified by Mowday et al. (1982). They are:

1) A strong desire to remain a member of the organization.

2) A strong belief in and acceptance of the values and goals of the organization.

3) A readiness to exert considerable effort on behalf of the organization.

According to Meyer and Allen (1991), organization commitment includes three kinds. They are listed below.

1) Affective commitment-A desire to maintain membership in the organization that develops largely as the result of work experiences that create feelings of comfort and personal competence.

2) Continuance commitment-Reflects a need to remain and results from recognition of the costs (e.g., existence of side bets, lack of alternatives) associated with leaving.

3) Normative commitment-An obligation to remain resulting from internalization of a loyalty norm and/or the receipt of favors that require repayment.

Albdour and Altarawneh's (2014) findings show that, employees who have high job engagement and organizational engagement have high level of affective commitment and normative commitment.

Saks (2006) states that organizational commitment is different from employee engagement, because organizational commitment is about one's attitude and attachment towards his/her organization. Macey and Schneider's (2008) view is that commitment might be a facet of employee engagement but it is not sufficient for employee engagement. Armstrong (2009) considered employee engagement and commitment as two constructs.

According to Armstrong (2009), employee engagement is job-oriented and commitment is organization-oriented. Commitment refers to attachment and loyalty. It is associated with the feelings of individuals about their organization.

Armstrong (2009) mentions that it is useful to distinguish between the two, because different policies may be required to enhance job engagement than those needed to increase organizational commitment. Armstrong (2009) illustrates the combinations of employee engagement and organizational commitment in Figure 1. Referring to Figure 1 researchers can say that Armstrong (2009) has identified organizational commitment and employee engagement as two constructs.

Carbonara (2012) says employee engagement refers to the level of dedication, commitment, passion, innovation and emotional energy a person is willing to expand. Researchers can say that Carbonara (2012) wants to state if the employees are engaged then they are committed. Cook (2008) points out being committed to the organization as a component of employee engagement. 


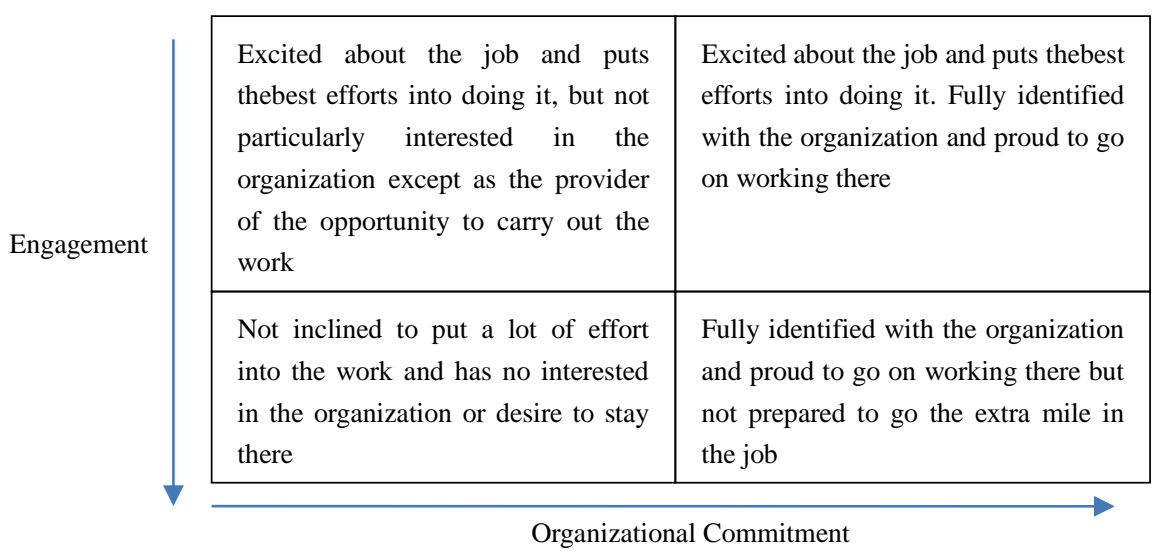

Figure 1. Combinations of engagement and organizational commitment

Source: Armstrong, 2009.

\subsection{Employee Engagement and Organizational Citizenship Behavior (OCB)}

Opatha (2009) mentions that organizational citizenship refers to the degree to which the employees are willing to engage in non-official behaviors that help the organization achieve its goals, as they love or wish its success and progress. Opatha (2009) further mentions that it involves a state in which an employee works for the benefit of the organization in addition to what he/she is supposed to perform on the job. Opatha (2009) provides examples of behaviors which include helping others to perform their duties, working overtime willingly when necessary, and coming to work on a holiday for a special need of the organization by sacrificing a personal trip planned to go on with family members. It is an objective of HRM to generate organizational citizenship within the employees of the organization and further it.

While OCB involves voluntary and informal behaviors that can help co-workers and the organization, the focus of engagement is one's formal role performance rather than extra-role and voluntary behavior (Saks, 2006). Rich et al. (2010) found that engagement mediated the relationship between three antecedents (value congruence, perceived organizational support, and core self-evaluations) and task performance and organizational citizenship behavior in a sample of firefighters.

\subsection{Employee Engagement and Job Satisfaction}

The term job satisfaction refers to an individual's general attitude towards his/her job. The likes and dislikes differ from individual to individual with respect to job contextual factors or job content factors. Job satisfaction involves feelings about a particular job or job experiences and feelings derive from an evaluation of the job (Opatha, 2015). Armstrong (2009) mentions that the concept of job satisfaction is closely linked to employee engagement.

Armstrong (2009) states that job satisfaction refers to the attitudes and feelings people have about their work. Armstrong (2009) further states that the negative and unfavorable attitudes towards the job indicate job dissatisfaction. Erickson, 2005, as cited in Macey and Schneider (2008), mention that although there may be room for satisfaction within the engagement construct, engagement connotes activation, whereas satisfaction connotes satiation. Pocket Oxford English Dictionary (2007) defines "satiate" as "giving someone as much or more than they want". AON Hewitt (2012) defines engagement through three attributes. One attribute is "Strive", which means that the employee exerts extra effort and engages in behaviors that contribute to business success. This substantiates that job satisfaction has a close relationship with employee engagement, but employee engagement is a broader term than job satisfaction. According to MacLeod and Clarke (2009) measuring satisfaction does not explain-how employees behave, but measuring engagement does.

\section{Is Employee Engagement a Behavior or an Attitude?}

Different researchers have been defined the construct called employee engagement in different ways. For some researchers it means an attitude and for some, a behavior.

Birmingham University English Language Dictionary (1987) defines "behavior" as given below.

1) A person's behavior is the way they act in general, especially in relation to the situation they are in or the people they are with. 
2) The behavior of something is the typical way in which it functions, according to the laws of science.

Dunham (1984) mentions that there are many behaviors apparent in the work force, but some are more common than others. Dunham (1984) further mentions that although several of these behaviors are important to organizations, those behaviors related to organizational participation, effort, performance and productivity are of special interest.

Participation is a person physically presenting at his/her organization. Participation is the degree to which a person actually participates in the organizational events. According to Dunham (1984) participation behaviors are timeliness, attendance and retention.

- Timeliness-the degree to which an organizational member arrives at work when he or she is expected.

- Attendance-whether or not an organizational member comes to work on a particular day. Dunham (1984) further states that it has been estimated that each 1 percent of absenteeism reduces productivity by up to 2.5 percent, due to the necessity for rescheduling production or reshuffling.

- Retention-retention occurs when an individual keeps a job with an organization. Turnover is the term used to describe the departure of one of its members from an organization.

Effort involves human behavior directed toward achieving performance. This does not mean that effort necessarily will lead to performance (Dunham, 1984).

Dunham (1984) considers performance as the behaviors of organizational members which help meet organizational objectives. Dunham (1984) further states that performance is obviously a function of effort. Without effort, performance cannot result. However, effort alone cannot cause performance, and there are many other factors which cause it.

Productivity is the output of individuals, groups, organizations or countries and the economic value of the output (Dunham, 1984). Productivity focuses heavily on quantity (i.e., the economic value of output). Productivity rates are typically figured on the basis of the value of output per hour of employee pay. As such, productivity is influenced not only by performance but also by absenteeism (Dunham, 1984).

Dunham (1984) states that timeliness is the degree to which organizational members arrive at work when they are expected. Researchers can say that one characteristic of an engaged employee is timeliness. Langford (2009), as cited in Smith and Langford (2011), shows that employee engagement correlates significantly with absenteeism and employee turnover, as well as safety, productivity, customer satisfaction, organizational goal attainment and profitability. Ludwig and Frazier (2012) point out, based on a "Positive Psychology" approach, that engagement is perceived as a valuable state for employees, because surveys on the construct have found it correlates with some organizational tactics (e.g. human resource policies, procedural justice) and positive outcomes (e.g. growth, lower costs, lower absenteeism). Richman (2006) points out how recent studies have made it clear that high employee engagement translates into increased discretionary effort, higher productivity and lower turnover at the employee level, as well as increased customer satisfaction and loyalty, profitability and shareholder value for the organization.

An engaged employee, as defined by Bevan et al. (1997) in Armstrong (2009), is someone "who is aware of the business context, and works closely with the colleagues to improve performance within the job for the benefit of the organization". Towers Perrin (2003) defines employee engagement as employees' willingness and ability to contribute to company success. Towers Perrin (2003) further states that engagement is the extent to which employees put the discretionary effort into their work, in the form of extra time, brainpower and energy.

AON Hewitt (2013) defines engagement through three attributes that include the extent to which employees:

Say-speak positively about the organization to co-workers, potential employees and customers;

Stay-have an intense sense of belonging and desire to be a part of the organization;

Strive-are motivated, and exert effort toward success in their job and of the company.

Gallup (2013) groups employees into one of three categories: Engaged, not engaged, and actively disengaged, based on his rationale that "engaged employees are the best colleagues". In building an organization, institution, or agency and maintaining its good standards, the engaged employees' contribution is immense. They lean towards new and better ways to achieve outcomes while being $100 \%$ psychologically committed to their work. Importantly, without deviating from their original scope of their jobs, they are capable of creating new customers. As mentioned in Gallup's (2013) report, identifying not engaged workers, provided that they are not hostile or disruptive, can be difficult. Their concerns do not revolve around customers, productivity, profitability, waste, 
safety, mission and purpose of the teams, or developing customers. They are rather concerned about wasting time thinking of various other things which include evening-gatherings or domestic matters. Existence of such "checked out" employees is observable in sales teams, support staffs as well as executive committees. In Gallup's (2013) report, it is specifically mentioned how actively disengaged employees take part in damaging the company; by monopolizing managers' time; having more on the-job accidents; accounting for more quality defects; contribute to "shrinkage," as theft is called; being sicker; missing more days; and quitting at a higher rate than engaged employees do. In other words, whatever the engaged employees do to contribute to the development of the company, is undone by the actively disengaged employees.

Pocket Oxford English Dictionary (2007) defines attitude as a way of thinking or feeling about someone or something. There are many work related attitudes such as job satisfaction, job involvement, and organizational commitment (Karia \& Asaari, 2006; Wright, 2006; Alas, 2005; Opatha, 2012).

Saks (2006) brings to light the contrast between the employee engagement and other constructs. The view of Saks (2006) is that employee engagement is a distinct and unique construct with cognitive, emotional and behavioral components which are linked with individual role performance. Saks (2006) further states that employee engagement is recognized as different from several related constructs such as organizational citizenship behavior, organizational commitment and job involvement. Macey and Schneider (2008) state that what is common to these definitions is the notion that employee engagement is a desirable condition, has an organizational purpose, and connotes involvement, commitment, passion, enthusiasm, focused effort, and energy; it has both attitudinal and behavioral components.

\section{Towards a Working Definition of Employee Engagement}

\subsection{Review of Employee Engagement Definitions}

Several definitions of engagement are prevalent in the literature. According to Andrew and Sofian (2012), Kahn (1990) becomes the first researcher who considered that employee engagement means one's psychological presence when executing his/her organizational task. Kahn (1990) defined employee engagement as "the harnessing of organization members' selves to their work roles; in engagement, people employ and express themselves physically, cognitively, and emotionally during role performances". Researchers' idea is that this definition explains the concept of engagement as a demonstration of being "present at work". It is essential to have a particular mental state to be "present at work" because, to be engaged, an individual has to think, feel and act on their job. This idea can be strengthened by Dharmasiri's (2010) definition. Dharmasiri (2010) states that it [employee engagement] captures the essence of employees' head, hands and heart involvement in work. Dharmasiri (2010) further states that it [employee engagement] refers to the psychological state of the employee (e.g. employee's identification with the organization), disposition of the employee (e.g. employee's positive feeling towards the organization) and performance (e.g. employee's level of discretionary effort). In brief, employee engagement captures cognitive (thinking), affective (feeling) and behavioral (acting) dimensions of an employee. Shuck and Wollard (2010) have defined employee engagement as "an individual employee's cognitive, emotional and behavioral state directed toward desired organizational outcomes".

Maslach and Leiter (1998) defined employee engagement as an energetic state of involvement with personally fulfilling activities that enhance one's sense of professional efficacy. Schaufeli et al. (2002) define engagement as a "positive, fulfilling, work-related state of mind that is characterized by vigor, dedication, and absorption". Schaufeli et al. (2002) further state that engagement is not a momentary and specific state, but rather, it is "a more persistent and pervasive affective-cognitive state that is not focused on any particular object, event, individual or behavior". Employee engagement refers to the individual's involvement and satisfaction with as well as enthusiasm for work (Harter et al., 2002).

An engaged employee as defined by Bevan et al. (1997) in Armstrong (2009) is someone "who is aware of business context, and works closely with colleagues to improve performance within the job for the benefit of the organization". Bevan et al. (1997), in Armstrong (2009), highlights the concept called "team work" with the statement "works closely with colleagues to improve performance". Some authors believe employee engagement is a combination of behavior and attitude. The definition by Storey et al. (2009) for employee engagement is: A set of positive attitudes and behaviors enabling high job performance of a kind which is in tune with the organization's mission. AON Hewitt (2012) defines engagement as the state of emotional and intellectual involvement that motivates employees to do their best work. AON Hewitt (2012) further states that engagement is an individual psychological and behavioral state. AON Hewitt (2012) points out that engagement outcomes as Say, Stay and Strive.

Engagement is characterized by employees being committed to the organization, believing in what it stands for 
and being prepared to go above and beyond what is expected of them to deliver an outstanding service to the customer (Cook, 2008). According to Cook (2008) engagement can be summed up by how positively the employee:

- Thinks about the organization

- Feels about the organization

- Is proactive in relation to achieving organizational goals for customers, colleagues and other stakeholders

Cook (2008) has been influenced by commitment and organizational citizenship behavior when defining employee engagement. There are many dimensions of employee engagement. Cook (2008) mainly pays his attention to the dimension called "customer satisfaction". Robbins and Judge (2013) mention that highly engaged employees have a passion for their work and feel a deep connection to their company. Also they define employee engagement as an individual's involvement with, satisfaction with, and enthusiasm for, the work she does. Below table presents employee engagement definitions considered for this paper.

Table 3. Employee engagement definitions

\begin{tabular}{|c|c|c|c|c|}
\hline Author & & Year & Definition & Comments \\
\hline Kahn & & 1990 & $\begin{array}{l}\text { The harnessing of organization members' selves to } \\
\text { their work roles; in engagement, people employ and } \\
\text { express themselves physically, cognitively, and } \\
\text { emotionally during role performances. }\end{array}$ & $\begin{array}{l}\text { - } \quad \text { This definition explains the concept of } \\
\text { engagement as a demonstration of being } \\
\text { "present at work". } \\
\text { - It is essential to have a particular mental state } \\
\text { to be "present at work" because, to be } \\
\text { engaged, an employee has to think, feel and } \\
\text { act on his/her job. }\end{array}$ \\
\hline $\begin{array}{l}\text { Maslach } \\
\text { Leiter }\end{array}$ & $\&$ & 1998 & $\begin{array}{l}\text { An energetic state of involvement with personally } \\
\text { fulfilling activities that enhance one's sense of } \\
\text { professional efficacy. }\end{array}$ & $\begin{array}{l}\text { - Employee engagement is a psychological } \\
\text { state. } \\
\text { - Involvement is a component of employee } \\
\text { engagement. }\end{array}$ \\
\hline $\begin{array}{l}\text { Schaufeli, } \\
\text { Salanova, } \\
\text { Roma } \\
\text { Bakker }\end{array}$ & $\&$ & 2002 & $\begin{array}{l}\text { Positive, fulfilling, work-related state of mind that is } \\
\text { characterized by vigor, dedication and absorption. }\end{array}$ & $\begin{array}{l}\text { - Engaged employees work hard (vigor). Hard } \\
\text { working is more towards a behavior. } \\
\text { Through 'work-related state of mind' the } \\
\text { authors want to say employee engagement is } \\
\text { a combination of behavior components and } \\
\text { psychological state. }\end{array}$ \\
\hline $\begin{array}{l}\text { Harter, Schn } \\
\& \text { Hayes }\end{array}$ & & 2002 & $\begin{array}{l}\text { Employee engagement refers to the individual's } \\
\text { involvement and satisfaction with as well as } \\
\text { enthusiasm for work. }\end{array}$ & $\begin{array}{l}\text { Involvement is a component of employee } \\
\text { engagement. } \\
\text { - } \\
\text { Dunham's (1984) view is that job/work } \\
\text { involvement is a psychological variable. } \\
\text { - } \quad \text { Harter et al., (2002) see employee } \\
\text { engagement has a psychological component. }\end{array}$ \\
\hline Cook & & 2008 & $\begin{array}{l}\text { Engagement is characterized by employees being } \\
\text { committed to the organization, believing in what it } \\
\text { stands for and being prepared to go above and } \\
\text { beyond what is expected of them to deliver } \\
\text { outstanding service to the customer. }\end{array}$ & $\begin{array}{l}\text { Influenced by: } \\
\begin{array}{l}\text { 1. Commitment. } \\
\text { 2. Organizational citizenship behavior. }\end{array}\end{array}$ \\
\hline $\begin{array}{l}\text { Macey } \\
\text { Schneider }\end{array}$ & $\&$ & 2009 & $\begin{array}{l}\text { Employee engagement is a desirable condition, has } \\
\text { an organizational purpose, and connotes } \\
\text { involvement, commitment, passion, enthusiasm, } \\
\text { focused effort, and energy; it has both attitudinal and } \\
\text { behavioral components. }\end{array}$ & $\begin{array}{l}\text { Engagement has both attitudinal and behavioral } \\
\text { components. }\end{array}$ \\
\hline
\end{tabular}




\begin{tabular}{|c|c|c|c|c|}
\hline $\begin{array}{l}\text { Storey, Ulric } \\
\text { Welbourne } \\
\text { Wright }\end{array}$ & ch, & 2009 & $\begin{array}{l}\text { A set of positive attitudes and behaviors enabling } \\
\text { high job performance of a kind which is in tune with } \\
\text { the organization's mission. }\end{array}$ & $\begin{array}{l}\text { Employee engagement is a combination of behavioral } \\
\text { and psychological components. }\end{array}$ \\
\hline $\begin{array}{l}\text { Shuck } \\
\text { Wollard }\end{array}$ & $\&$ & 2010 & $\begin{array}{l}\text { An individual employee's cognitive, emotional and } \\
\text { behavioral state directed toward desired } \\
\text { organizational outcomes. }\end{array}$ & $\begin{array}{l}\text { Employee engagement is a combination of behavioral } \\
\text { and psychological outcomes. }\end{array}$ \\
\hline Dharmasiri & & 2010 & $\begin{array}{l}\text { It [employee engagement] captures the essence of } \\
\text { employees' head, hands and heart involvement in } \\
\text { work. }\end{array}$ & $\begin{array}{l}\text { Kahn's (1990) idea can be strengthened by Dhasmasiri's } \\
\text { (2010) definition. }\end{array}$ \\
\hline AON Hewitt & & 2012 & $\begin{array}{l}\text { The state of emotional and intellectual involvement } \\
\text { that motivates employees to do their best work. } \\
\text { Engagement is an individual psychological and } \\
\text { behavioral state. }\end{array}$ & $\begin{array}{l}\text { Engagement is a combination of psychological and } \\
\text { behavioral components. }\end{array}$ \\
\hline AON Hewitt & & 2013 & $\begin{array}{l}\text { Engagement as the psychological and behavioral } \\
\text { outcomes that lead to better employee performance. }\end{array}$ & 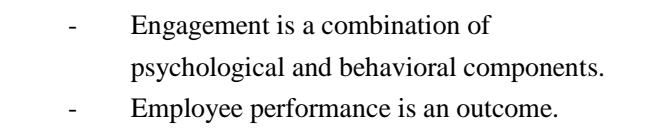 \\
\hline $\begin{array}{l}\text { Robbins } \\
\text { Judge }\end{array}$ & $\&$ & 2013 & $\begin{array}{l}\text { Engagement as an individual's involvement with, } \\
\text { satisfaction with, and enthusiasm for, the work she } \\
\text { does. }\end{array}$ & Influence with involvement. \\
\hline AON Hewitt & & 2014 & $\begin{array}{l}\text { Engagement as the psychological state and } \\
\text { behavioral outcomes that lead to better performance. }\end{array}$ & $\begin{array}{l}\text { Engagement is a combination of } \\
\text { psychological and behavioral components. } \\
\text { Employee performance is an outcome. }\end{array}$ \\
\hline
\end{tabular}

The review of the definitions of employee engagement clearly suggests a lack of compromise among researchers regarding what the precise meaning of the construct called "employee engagement" should be. Different researchers have defined the construct called employee engagement in different ways.

According to Andrew and Sofian (2012), Kahn (1990) was the first researcher who introduced employee engagement as one's psychological presence when executing his/her organizational task. Schaufeli et al. (2001) defined employee engagement as a psychological state. On the other hand Bevan et al. (1997) believe that engagement is a behavior. Storey et al. (2009); Macey and Schneider (2009); Shuck and Wollard (2010); AON Hewitt (2012); AON Hewitt (2013) and AON Hewitt (2014) believe employee engagement to be a combination of psychological state and behavioral outcomes.

Researchers believe that employee engagement is unique, and it is a combination of behavior and attitude. It is evident that employee engagement has a relationship with organizational commitment, organizational citizenship behavior, job involvement and work involvement. Out of these work related attitudes, the constructs of job involvement and work involvement are closely associated with employee engagement. With this understanding a working definition of employee engagement is constructed. With the working definition given below we specify precisely what we mean when we use the term employee engagement.

\subsection{Employee Engagement-Working Definition}

Employee Engagement is the extent to which an employee gets involved in the job and the organization cognitively, emotionally and behaviorally.

\section{Dimensions of Employee Engagement}

In this paper, employee engagement is conceptualized as a system which basically consists of three dimensions such as cognitive involvement, emotional involvement and behavioral involvement. Robbins and Judge (2013) state that attitude is an evaluative statement or judgment concerning objects, people, or events. Robbins and Judge (2013) further state that attitudes have three components; namely, cognition, affect and behavior.

Employee engagement is a combination of behavior and attitude. The dimension called "behavioral involvement" is not a component of attitude. Under attitude the behavioral component is about intention. Behavioral 
involvement is about employee's action. So the behavioral involvement dimension is considered as a behavior. The dimensions called "cognitive involvement" and "emotional involvement" are considered as attitudes.

\subsection{Cognitive Involvement}

Robbins and Judge (2013) state that cognitive component of the attitude is the opinion or belief segment of an attitude. Dunham (1984) did consider work or a job to be a central life interest; as a component of work and job involvement. Researchers believe that employee engagement is closely related with the existing constructs of job involvement and work involvement. Therefore engaged employees consider work or a job to be a central life interest. The element called "central life interest" derives from this component. Dunham (1984) states that following statements might be made by a person who is high in the central life interest component.

-The most important things that happen to me is involving in my work/job

-The major satisfaction in my life comes from my work/job

-I live, eat and breathe in my work/job

The dimension called cognitive involvement is measured by statements such as, (1) I think the most important thing that happened to me is involvement in my work/job (2) I believe the major satisfaction in my life comes from my work/job (3) I believe I live, eat and breathe with my work/job. Table 4 presents the elements and statements of the dimension called cognitive involvement.

Table 4.Elements and statements of the dimension called cognitive involvement

\begin{tabular}{lll}
\hline Element & & Statement \\
\hline \multirow{3}{*}{ Central life interest } & $\bullet$ & I think the most important thing that happened to me is involvement in my work/job. \\
& - & I believe the major satisfaction in my life comes from my work/job. \\
& - & I believe I live, eat and breathe with my work/job. \\
\hline
\end{tabular}

\subsection{Emotional Involvement}

Robbins and Judge (2013) mention that emotional component of an attitude is the emotional or feeling-segment of an attitude. Dunham (1984) declares that "conscious desire and choice to participate in work or a job" and "consider work or a job to be central to his/her self-concept" are components of work and job involvement. These are considered to be elements of the dimension of emotional involvement.

The dimension called emotional involvement is measured by statements such as (1) When my boss assigns a job/task I feel, I'm really going to "get into" this job/task (2) I feel proud of the work I do (3) I am proud to introduce myself with my job title. Table 5 presents the elements and statements of the dimension called emotional involvement.

Table 5. The elements and statements of the dimension called emotional involvement.

\begin{tabular}{|c|c|}
\hline Element & Statement \\
\hline $\begin{array}{l}\text { Conscious desire and choice to participate in work } \\
\text { or a job }\end{array}$ & $\begin{array}{l}\text { - When my boss assigns a job/task I feel, I'm really going to "get into" this } \\
\text { job/task. }\end{array}$ \\
\hline $\begin{array}{l}\text { Consider work or a job to be central to his/her } \\
\text { self-concept }\end{array}$ & $\begin{array}{l}\text { - I feel proud of the work I do. } \\
\text { - } \quad \text { I am proud to introduce myself with my job title. }\end{array}$ \\
\hline
\end{tabular}

\subsection{Behavioral Involvement}

According to Dunham (1984), the behaviors apparent in the work force are participation and effort. According to him, specific participation behaviors are timeliness, attendance and retention. The AON Hewitt Engagement Model provides engagement outcomes as Say, Stay and Strive, which are also considered as elements of behavioral involvement. One of Dunham's (1984) participation behaviors called "Retention" comes under "Stay".

The dimension called behavioral involvement is measured by statements such as (1) I always arrive at work when I'm expected to arrive (2) Generally I'm not a person of absenteeism (3) I exert high level of effort to perform duties of my job (4) I speak positively about the organization when interacting with others (5) I have no intention to resign from my job (6) I strive towards achieving duties in the expected way by my organization. 
Table 6 gives the elements and statements of the dimension called behavioral involvement.

Table 6. Elements and statements of the dimension called behavioral involvement.

\begin{tabular}{lll}
\hline Element & & Statement \\
\hline Timeliness & - & I always arrive at work when I'm expected to arrive. \\
Attendance & - & Generally I'm not a person of absenteeism. \\
Effort & - & I exert high level of effort to perform duties of my job. \\
Say & - & I speak positively about the organization when interacting with others. \\
Stay & - I have no intention to resign from my job. \\
Strive & - & I strive towards achieving duties in the expected way by my organization. \\
\hline
\end{tabular}

Accordingly the construct of employee engagement has believing dimension, feeling dimension, and action dimension. Figure 2 diagrams the dimensions and elements of the variable of employee engagement. In the Figure (D) stands for a dimension and (E) stands for an element of the variable of Employee Engagement. Based on the statements given above it will be possible to develop an instrument to measure the construct of employee engagement.

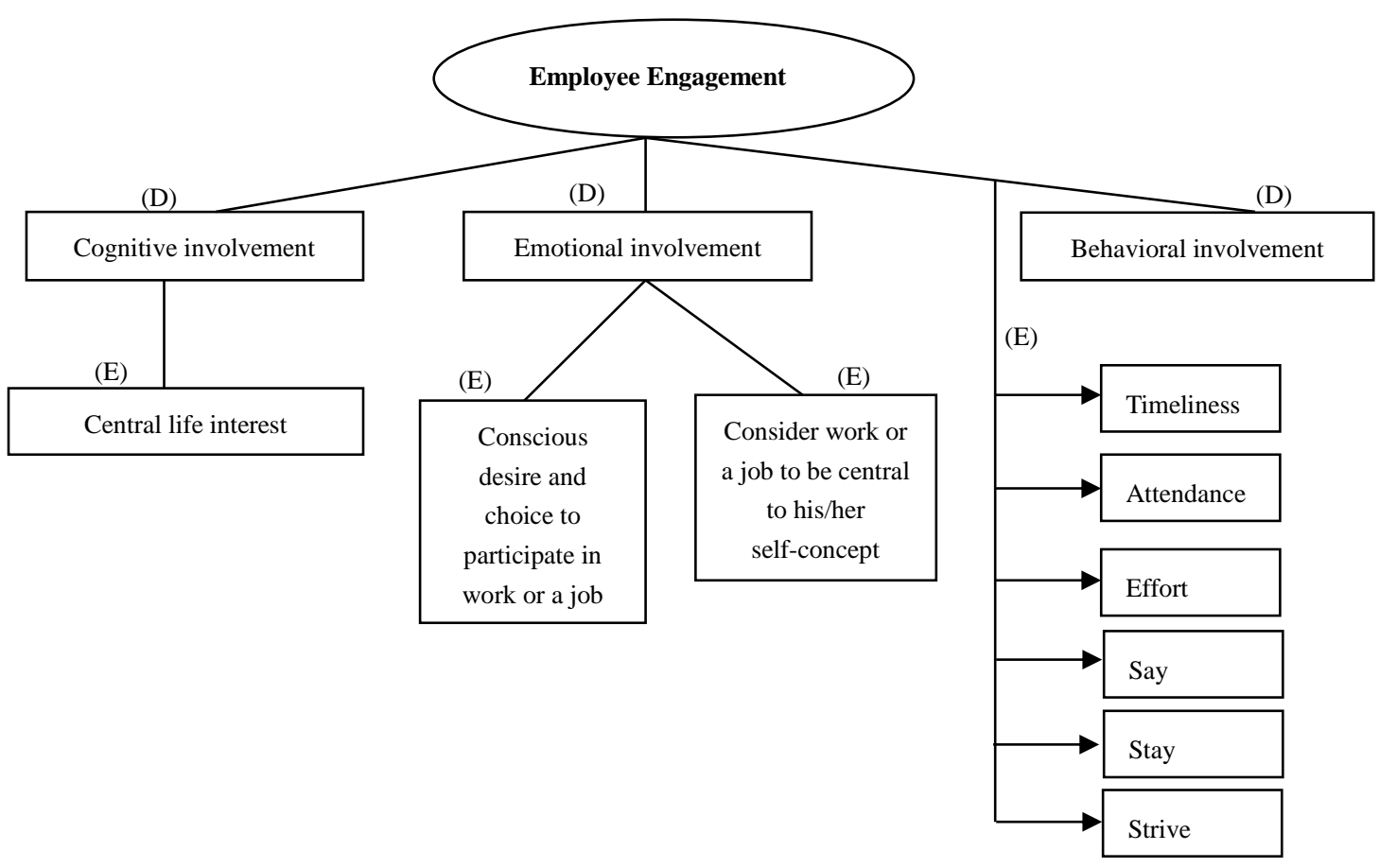

Figure 2. Dimensions and elements of the variable of employee engagement

\section{Conclusion}

There is a common thread between all the labels such as job engagement, organizational engagement, work engagement, personal engagement and employee engagement. The researchers prefer the term employee engagement, because the word "employee" is about a living being. It should be employee engagement in job and organization.

Indeed there is a conceptual confusion with regard to the meaning of employee engagement. Employee engagement is a unique concept, but it is closely related to job involvement and work involvement. Since employee engagement is considered as the extent to which an employee gets involved in the job and the organization, it shows that employee engagement is broader than job involvement and work involvement. Employee engagement is a specific phenomenon, though it is related to job satisfaction, organizational commitment, organizational citizenship behavior, job involvement and work involvement. Researchers believe that employee engagement is a combination of behavior and attitude. 
Researchers have identified three dimensions; namely cognitive involvement, emotional involvement and behavioral involvement of the variable of employee engagement. Relevant certain elements under each dimension have been explored and they could be used to develop an instrument to measure employee engagement.

\section{References}

Alas, R. (2005). Job related attitudes and ethics in countries with different histories. Cross Cultural Management: An International Journal, 12(2), 69-84. http://dx.doi.org/10.1108/13527600510798024

Allen, T. D., Freeman, D. M., Russell, J. E. A., Reizenstein, R. C., \& Rentz, J. O. (2001). Survivor reactions to organizational downsizing: Does time ease the pain? Journal of Occupational and Organizational Psychology, 74, 145-164. http://dx.doi.org/10.1348/096317901167299

Andrew, O. C., \& Sofian, S. (2012). Individual Factors and Work Outcomes of Employee Engagement. Procedia-Social and Behavioral Sciences, 40, 498-508. http://dx.doi.org/10.1016/j.sbspro.2012.03.222

Anitha, J. (2014). Determinants of employee engagement and their impact on employee performance. International Journal of Productivity and Performance Management, 63(3), 308-323. http://dx.doi.org/10.1108/IJPPM-01-2013-0008

Anaza, N. A., \& Rutherford, B. (2012). How organizational and employee-customer identification, and customer orientation affect job engagement. Journal of Service Management, 23(5), 616-639. http://dx.doi.org/10.1108/09564231211269801

AON, H. (2012). 2012 Trends in Global Employee Engagement. Retrieved from http://www.aon.com/attachments/human-capital-consulting/2012_TrendsInGlobalEngagement_Final_v11.p df

AON, H. (2013). 2013 Trends in Global Employee Engagement. Retrieved from http://www.aon.com/attachments/human-capital-consulting/2013_Trends_in_Global_Employee_Engageme nt_Highlights.pdf

Armstrong, M. (2009). Armstrong's Handbook of Human Resource Management Practice (11th ed.). London and Philadelphia: Kogan Page.

Albdour, A. A., \& Altarawneh, I. I. (2014). Employee Engagement and Organizational Commitment: Evidence from Jordan. International Journal of Business, 19(2), 192-212.

Bakker, A. B., \& Demerouti, E. (2008). Towards a model of work engagement Department of Work and Organizational Psychology. Career Development International, 13(3), 209-223. http://dx.doi.org/10.1108/13620430810870476

Byrne, Z. S. (2015). Understanding Employee Engagement: Theory, Research, and Practice. New York: Routledge.

Carbonara, S. (2013). Manager's Guide to Employee Engagement. New York: McGraw-Hill.

Cook, S. (2008). The Essential Guide to Employee Engagement, Kogan Page Limited, London and Philadelphia. Collins Birmingham University International Language Database (Cobuild) English Language Dictionary. London: Collins.

Dharmasiri, A. S. (2010). Epitome of Engaging Employees. 22nd Anniversary Convention Volume of Association of Professional Bankers-Sri Lankar Retrieved from http://www.apbsrilanka.org/articales/22_ann_2010/2010_a_7_Dr_Ajantha_Dharmasiri.pdf

Dunham, R. B. (1984). Organizational Behaviour. Illionois: IRWIN, United States of America.

Gorgievski, M. J., Bakker, A. B., \& Schaufeli, W. B. (2010). Work engagement and work holism: Comparing the self-employed and salaried employees. The Journal of Positive Psychology, 5(1), 83-96.

Gallup. (2013). State of the American Workplace Report. Retrieved fromhttp://employeeengagement.com/wp-content/uploads/2013/06/Gallup-2013-State-of-the-American-Wo rkplace-Report.pdf

Guest, D. (2014). Employee engagement: A sceptical analysis. Journal of Organizational Effectiveness: People and Performance, 1(2), 141-156. http://dx.doi.org/10.1108/JOEPP-04-2014-0017

Harter, J. K., Schmidt, F. L., \& Hayes, T. L. (2002). Business-unit level relationship between employee satisfaction, employee engagement, and business outcomes: A meta-analysis. Journal of Applied 
Psychology, 87, 268-79.

Hallberg, U. E., \& Schaufeli, W. B. (2006). Same same, but different? Can work engagement be discriminated from job involvement and organizational commitment? European Phychologist, 119-127. http://dx.doi.org/10.1037/0021-9010.87.2.268

Joo, B. K., \& Mclean, G. N. (2006). Best employer studies: A conceptual model from a literature review and a case study. Human Resource Development Review, 528-258. http://dx.doi.org/10.1177/1534484306287515

Kahn, W. A. (1990). Psychological conditions of personal engagement and disengagement at work. Academy of Management Journal, 33(4), 692-724.

Karia, N., \& Asaari, M. H. A. H. (2006). The effects of total quality management practices on employees' workrelated attitudes. The TQM Magazine, 18(1), 30-43. http://dx.doi.org/10.1108/09544780610637677

Karatepe, O. M. (2013). Perceptions of organizational politics and hotel employee outcomes: The mediating role of work engagement. International Journal of Contemporary Hospitality Management, 25, 82-104. http://dx.doi.org/10.1108/09596111311290237

Luthans, F., \& Perterson, S. J. (2002). Employee engagement and manager self-efficacy-Implications for managerial effectiveness and development. Journal of Management Development, 21(5), 376-387. http://dx.doi.org/10.1108/02621710210426864

Ludwig, T. D., \& Frazier, C. B. (2012). Employee Engagement and Organizational Behavior Management. $\begin{array}{lllll}\text { Journal of } \quad \text { Organizational } & \text { Behavior }\end{array}$ http://dx.doi.org/10.1080/01608061.2011.619439

Maslach, C., \& Leiter, M. P. (2008). Early predictors of job burnout and engagement. Journal of Applied Psychology, 93(3), 498-512. http://dx.doi.org/10.1037/0021-9010.93.3.498

May, D. R., Gilson, R. L., \& Harter, L. M. (2004). The psychological conditions of meaningfulness, safety and availability and the engagement of the human spirit at work. Journal of Occupational and Organizational Psychology, 77, 11-37. http://dx.doi.org/10.1348/096317904322915892

Macey, W. H., \& schneider, B. (2008). The Meaning of Employee Engagement. Industrial and Organizational Psychology, 1, 3-30. http://dx.doi.org/http://dx.doi.org/10.1111/j.1754-9434.2007.0002.x

Meyer, J. P., \& Allen, N. J. (1991). A three-component conceptualization of organizational commitment. University of Western Ontario, 1(1). http://dx.doi.org/10.1016/1053-4822(91)90011-Z

Macleod, D., \& Clarke, N. (2009). Engaging for success: Enhancing performance through employee engagement. London: Office of Public Sector Information.

Opatha, H. H. D. N. P. (2009). Human Resource Management: Personnel. Department of HRM, University of Sri Jayewardenepura, Sri Lanka.

Opatha, H. H. D. N. P. (2012). Human Resource Management: Personnel. Department of HRM, University of Sri Jayewardenepura, Sri Lanka.

Opatha, H. H. D. N. P. (2015). Organizational Behaviour: The Human Side of Work. Department of HRM, University of Sri Jayewardenepura, Sri Lanka.

Rich, B. L., Lepine, J. A., \& Crawford, E. R. (2010). Job Engagement: Antecedents and Effects on Job Performance. Academy of Management Journal, 53(3), 617-635.

Richman, A. (2006). Everyone wants an engaged workforce how can you create it? Workspan,49, 36-9.

Robbins, S. P., \& Judge, T. A. (2013).Orgaanizational Behaviour (15th ed.). United States of America: Prentice Hall.

Robertson, I. T., \& Cooper, C. L. (2010). Full engagement: The integration of employee engagement and psychological well-being.Leadership \& Organization Development Journal, 31(4), 324-336. http://dx.doi.org/10.1108/01437731011043348

Saks, A. M. (2006). Antecedents and consequences of employee engagement. Journal of Managerial Psychology, 21(7), 600-619. http://dx.doi.org/10.1108/02683940610690169

Smith, V., \& Langford, P. (2011). Responsible or redundant? Engaging the workforce through corporate social responsibility. Australian Journal of Management, 36(3), 425-447. 
http://dx.doi.org/10.1177/0312896211415459

Saks, A. M., \& Gruman, J. A. (2014). What Do We Really Know About Employee Engagement? Human Resource Development Quarterly, 25(2), 155-182. http://dx.doi.org/10.1002/hrdq.21187

Storey, J., Ulrich, D., \& Wright, P. M. (2009). The Routledge Companion to Strategic Human Resource Management. Routledge, 299- 315.

Shuck, M. B., Rocco, T. S., \& Albornoz, C. A. (2011). Exploring employee engagement from the employee perspective: Implications for HRD. Journal of European Industrial Training, 35(4), 300-325. http://dx.doi.org/10.1108/03090591111128306

Shuck, B., \& Wollard, K. (2010). Employee Engagement and HRD: A Seminal Review of the Foundations. Human Resource Development Review, 9(1), 89-110. http://dx.doi.org/10.1177/1534484309353560

Schaufeli, W. B., Martínez, I. M., Pinto, A. M., Salanova, M., \& Bakker, A. B. (2002). Burnout and Engagement in University Students, A Cross-National Study. Journal of Cross-Cultural Psychology. http://dx.doi.org/10.1177/0022022102033005003

Schaufeli, W. B., Salanova, M., González-romá, V., \& Bakker, A. B. (2002). The Measurement of Engagement and Burnout: A Two Sample Confirmatory Factor Analytic Approach. Journal of Happiness Studies, 3(1), 71-92.

Towers, P. (2003).Working Today: Understanding What Drives Employee Engagement The 2003 Towers Perrin Report. Retrieved

from http://www.keepem.com/doc_files/Towers_Perrin_Talent_2003\%28TheFinal\%29.pdf

Wright, T. A. (2006). The emergence of job satisfaction in organizational behavior: A historical overview of the dawn of job attitude research. Journal of Management History, 12(3), 262-277. http://dx.doi.org/10.1108/17511340610670179

Wegge, J., Schmidt, L. H., Parkes, C., \& Dick, R. V. (2007). Taking a sickie': Job satisfaction and job involvement as interactive predictors of absenteeism in a public organization. Journal of Occupational and Organizational Psychology, 80(1), 7-89. http://dx.doi.org/10.1348/096317906X99371

Xu, J., \& Thomas, H. C. (2011). How can leaders achieve high employee engagement? Leadership \& Organization Development Journal, 32(4), 399-416. http://dx.doi.org/10.1108/01437731111134661

\section{Copyrights}

Copyright for this article is retained by the author(s), with first publication rights granted to the journal.

This is an open-access article distributed under the terms and conditions of the Creative Commons Attribution license (http://creativecommons.org/licenses/by/3.0/). 